\title{
Szívinfarktus 2016: gyakoriság, ellátás, prognózis
}

\author{
Jánosi András*
}

\author{
Gottsegen György Országos Kardiológiai Intézet, Nemzeti Szívinfarktus Regiszter, Budapest \\ Levelezési cím: Prof. Dr. Jánosi András, Gottsegen György Országos Kardiológiai Intézet, Nemzeti Szívinfarktus Regiszter \\ Budapest, 1096. Haller u 29. E-mail:janosi.andras@kardio.hu
}

A szerző a Nemzeti Szívinfarktus Regiszter (NSZR) 2016. évi eredményeit ismerteti és összefoglalja a szívinfarktus miatt kezelt betegek ellátásával kapcsolatos hazai adatokat, amelyet a SWEDEHEART-program eredményeivel vet össze. Az NSZR-ben a 2016. évben a finanszírozott szívinfarktusos események 87,9\%-ának klinikai adatai szerepelnek (14 462 beteg, 14766 esemény). A regisztrált események 41,8\%-a az ST-elevációval járó (STEMI), 58,2\%-a nem ST-elavációval járó szívinfarktus (NSTEMI) diagnózissal került rögzítésre. A STEMI-események 92,6\%-ában a betegek a szívkatéteres centrumban kaptak ellátást. Katéteres revaszkularizáció az események 83,2\%-ánál történt. Trombolízisre 28 betegnél $(0,38 \%)$ került sor. Az NSTEMI-diagnózissal kezelt betegek 56,7\%-ánál történt PCI. A 2015. évben kezelt STEMI-betegek 30 napos halálozása 12,9\%, az 1 éves halálozás 19,9\% volt. A PCl-kezelésben részesülteknél ezen értékek lényegesen alacsonyabbak: 9,1, illetve $15,1 \%$. Az NSTEMI-betegeknél ugyanezen évben a halálozási 11,8\%, illetve $23 \%$ volt. A PCl-kezelés ebben a betegcsoportban is lényegesen jobb prognózist biztosított: a halálozás $5,8 \%$, illetve $14,2 \%$. Az infarktusellátásra vonatkozó irányelv és a nemzetközi adatokkal történt összevetés alapján a magyarországi jelenlegi helyzet fö problémája, hogy igen hosszú a panasz kezdetétől az ér megnyitásáig eltelt idő: 2016-ban 120 percen belül mindössze a betegek 6,2\%-ánál került sor a primer PCIre. A STEMI-betegek jelentős része nem közvetlenül kerül az invazív centrumba (a primer transzport aránya $68 \%$ ), a beteg késése, illetve az áthelyezéssel kapcsolatos időveszteség miatt hosszú a teljes iszkémiás idő, ennek ellenére elhanyagolható a trombolízis alkalmazása $(0,38 \%)$. Joggal feltételezhető, hogy a jelenleginél gyakrabban lenne indokolt a prehospitális vagy kórházi a trombolízis alkalmazása. A SWEDEHEART-programban a betegek 3,7\%-ánál történt ilyen kezelés. Az 1 éves életkilátások javítása tekintetében a szekunder prevenció szempontjából fontos gyógyszeres kezelés perzisztenciájának, a szakgondozás arányának növelése valamint a minél szélesebb körü életmód-változtatás hozhat eredményt.

Kulcsszavak: szívinfarktus, STEMI, NSTEMI, PCI, szívinfarktus regiszter

\section{Myocardial infarction - 2016: frequency, medical care, prognosis}

The author recites the results of the Hungarian Myocardial Infarction Registry (HUMIR) coming from 2016 and summarizes national data related to the medical care of patients treated with myocardial infarction, which data then are compared with the results of the SWEDEHEART program. The HUMIR contains the clinical data of $87.9 \%$ of myocardial infarction cases financed in 2016 (14462 patients, 14766 cases). $41.8 \%$ of the registered cases were recorded as ST-elevation myocardial infarction (STEMI), whereas $58.2 \%$ of the cases were recorded as non-ST elevation myocardial infarction (NSTEMI). In $92.6 \%$ of the STEMI cases the patients were treated in the cardiac catheterization centre. Catheter revascularization took place in $83.2 \%$ of the cases. Thrombolysis took place in case of 28 patients $(0.38 \%) .56 .7 \%$ of the patients with NSTEMI diagnosis were treated with PCI. In 2015, $12.9 \%$ of STEMI patients died within 30 days, and $19.9 \%$ died within a year. In case of patients receiving $\mathrm{PCl}$ treatment these values are significantly lower: 9.1 and $15.1 \%$ respectively. In the same year the death rate of NSTEMI patients was $11.8 \%$ and $23 \%$. The $\mathrm{PCl}$ treatment also ensured significantly better prognosis in this patient group: the death rate was $5.8 \%$ and $14.2 \%$. On the basis of the comparison with the directive relating to the treatment of myocardial infarction as well as international data, currently the main problem in Hungary is that a long time elapses from the occurrence of the complaint until the coronary artery is opened up: in 2016 only $6.2 \%$ of the patients received primary $\mathrm{PCl}$ within 120 minutes. The great majority of STEMI patients do not get to the invasive centre directly (the proportion of primary transport is $68 \%$ ). Due to the late arrival of the patient and the loss of time resulting from the transfer the full ischaemic time is long. Despite this fact, the application of thrombolysis is negligible $(0.38 \%)$. It is reasonable to suppose that pre-hospital or in-hospital thrombolysis should be applied more often than now. In the SWEDEHEART program $3.7 \%$ of the patients received such treatment. In order to improve the 1-year survival period, increasing the persistence of medical treatment important in terms of secondary prevention and the proportion of specialised care as well as an extensive change in the way of life style may yield a result.

Keywords: myocardial infarction, STEMI, NSTEMI, myocardial infarction registry

*A Nemzeti Szívinfarktus Regiszter Program résztvevői nevében. 
A Nemzeti Szívinfarktus Regiszter (NSZR) múködése lehetővé teszi, hogy klinikailag releváns adatok álljanak rendelkezésre a heveny szívinfarktus miatt kezelt betegek számáról, az infarktus típusáról, az ellátás módjáról, a korai és az 1 éves halálozásról. Az adatok elemzése az aktuális helyzet megítélésén túlmenően arra is lehetőséget nyújt, hogy keressük azokat a pontokat, ahol javítható az ellátás. A fenti célok és elvek alapján müködő NSZR adatait Cardiologia Hungarica hasábjain évről évre közöljük (1).

\section{Az NSZR adatbázisának teljessége az adminisztratív adatokkal összehasonlítva}

Megvizsgáltuk, hogy mennyire teljes az NSZR adatbázisa. A megítéléshez regisztrált/finanszírozott események arányának alakulását vettük alapul. Adataink alapján a Regiszter adatbázisának teljessége folyamatosan nő: 2013-ban 51\%, 2014-ben 67\%, 2015-ben 71,3\%, 2016 -ban $87,9 \%$. volt. Tekintettel arra, hogy az infarktusos betegek döntő hányada szívkatéteres centrumban kerül ellátásra, az 1. táblázatban az egyes szívkatéteres centrumokra lebontva vizsgáltuk a kezelt (az OEP által finanszírozott) és a regiszterben rögzített betegek arányát. Látható, hogy a rögzítési fegyelem a centrumok között jelentősen eltér, de többségében eléri vagy meghaladja a $90 \%$-ot.

\section{A különböző típusú szívinfarktusok} (ST-elevációval járó, nem ST-elevációval járó) elófordulási gyakorisága

A 2016. évben regisztrált infarktusos események 41,8\%-a a STEMI, 58,2\%-a NSTEMI-diagnózissal került rögzítésre. Az előző évekhez hasonlóan ebben az évben is nőtt az NSTEMI-események részaránya.

\section{Az ST-elevációval járó szívinfarktusos betegek (STEMI) ellátása, a primer PCI gyakorisága}

A STEMI-események 92,6\%-ában a betegek szívkatéteres centrumban kaptak ellátást. A primer transzport aránya $68,8 \%$ volt. ami az előbbi évhez viszonyítva néhány \%-os növekedést jelent. Katéteres revaszkularizáció a betegek 83,2\%-ánál történt. Trombolízis 28 betegnél $(0,38 \%)$ történt (14 prehospitalisan, 14 kórházban). A prehospitális trombolízis döntő része (14-ből 9) a Hajdú-Bihar megyei régióban történt. A gyógyszeres revaszkularizációt 18 esetben követte katéteres érmegnyitás. A szívkatéteres centrumba felvett betegek esetén a panasz kezdete és az infarktusért felelős ér megnyitása közötti időt az események háromnegyedénél (74\%) ismerjük. Az panasz kezdetétől a szívkatéteres laboratóriumba érkezésig idő mediánja 4 óra 34 perc volt, míg az ajtó-ballon idő 40 perc. A késlekedési idő döntő része tehát a prehospitális időszakra esik (beteg késlekedése, sze-

1. TÁBLÁZAT. A szívkatéteres centrumokban finanszírozott és a regisztrált események száma

\begin{tabular}{|c|c|c|c|c|}
\hline \multirow[t]{2}{*}{ Kórház } & \multicolumn{4}{|c|}{ A finanszírozott betegek rögzítési aránya szívkatéteres centrumokban } \\
\hline & 2013 & 2014 & 2015 & $\begin{array}{c}\mathbf{2 0 1 6} \\
90,38 \%\end{array}$ \\
\hline Bajcsy & $72,00 \%$ & $79,00 \%$ & $94,21 \%$ & $83,25 \%$ \\
\hline Balatonfüred & $87,80 \%$ & $62,70 \%$ & $100,00 \%$ & $100,00 \%$ \\
\hline $\mathrm{BIK}$ & $65,90 \%$ & $31,60 \%$ & $72,56 \%$ & $62,73 \%$ \\
\hline Debrecen Kard. & $74,60 \%$ & $91,00 \%$ & $75,57 \%$ & $62,84 \%$ \\
\hline GOKI & $97,20 \%$ & $75,20 \%$ & $97,04 \%$ & $92,57 \%$ \\
\hline Győri Megyei Kh. & $54,00 \%$ & $57,00 \%$ & $93,63 \%$ & $96,28 \%$ \\
\hline Gyula & $57,80 \%$ & $60,30 \%$ & $40,11 \%$ & $95,96 \%$ \\
\hline Honvéd Kh. Bp. & $22,00 \%$ & $34,80 \%$ & $100,00 \%$ & $100,00 \%$ \\
\hline Kaposvár & $17,80 \%$ & $45,50 \%$ & $91,45 \%$ & $91,6 \%$ \\
\hline Kecskemét & $99,50 \%$ & $95,40 \%$ & $100,00 \%$ & $82,00 \%$ \\
\hline Miskolc & $72,40 \%$ & $49,60 \%$ & $69,73 \%$ & $99,51 \%$ \\
\hline Nyíregyháza & $11,90 \%$ & $96,90 \%$ & $95,94 \%$ & $96,94 \%$ \\
\hline PTE Szívgyógyászat & $26,50 \%$ & $73,50 \%$ & $96,89 \%$ & $99,83 \%$ \\
\hline SE Szív- és Érgyógyászati Klinika & $50,00 \%$ & $68,10 \%$ & $100,00 \%$ & $98,67 \%$ \\
\hline Szeged Kard. & $40,00 \%$ & $39,60 \%$ & $88,55 \%$ & $78,63 \%$ \\
\hline Székesfehérvár & $58,60 \%$ & $68,40 \%$ & $77,04 \%$ & $97,73 \%$ \\
\hline Szolnok & $64,90 \%$ & $76,10 \%$ & $86,92 \%$ & $98,13 \%$ \\
\hline Szombathely & $95,40 \%$ & $63,20 \%$ & $93,52 \%$ & $94,95 \%$ \\
\hline Zalaegerszeg & $81,30 \%$ & $84,20 \%$ & $100,00 \%$ & $98,91 \%$ \\
\hline
\end{tabular}


LERCATON

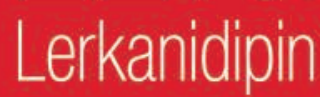

Enyhe és középsúlyos esszenciális hipertónia kezelésére(1)

\section{Alacsony gyakoriságú perifériás ödéma ${ }^{(1)}$}
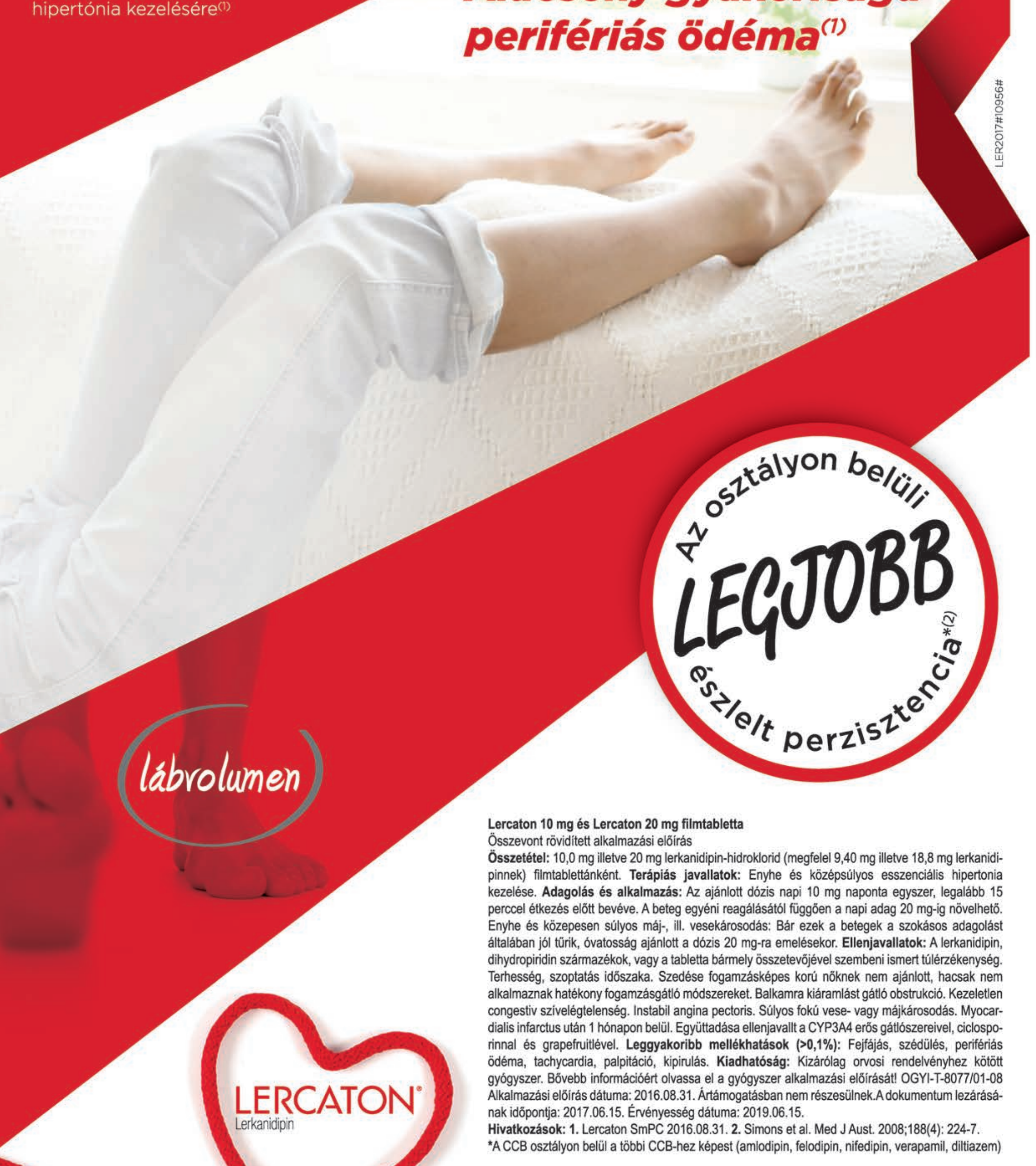
2. TÁBLÁZAT. Az invazív centrumok által ellátott STEMI betegek lakóhely szerinti megoszlása

\begin{tabular}{|c|c|c|c|c|}
\hline Centrum & $\begin{array}{c}\text { Az a megye } \\
\text { ahonnan a legtöbb } \\
\text { beteg érkezett }\end{array}$ & $\begin{array}{c}\text { Az a megye, } \\
\text { ahonnan jelentős } \\
\text { számú beteg érkezett }\end{array}$ & $\begin{array}{l}\text { Az összes többi } \\
\text { helyröl érkezett } \\
\text { beteg }\end{array}$ & $\begin{array}{c}\text { Összes } \\
\text { beteg }\end{array}$ \\
\hline Miskolc & BAZ $(n=484)$ & Heves $(n=153)$ & 16 & 653 \\
\hline SE VSZÉK & Budapest (n=265) & Pest $(n=192)$ & 99 & 556 \\
\hline Honvéd Kórház & Budapest (n=263) & Pest (n=127) & 125 & 515 \\
\hline Szeged & Csongrád (n=262) & Bács (n=101) & 17 & 380 \\
\hline Székesfehérvár & Fejér (n=216) & Komárom (n=97) & 61 & 374 \\
\hline Nyíregyháza & Sz-SZ-B (n=338) & $\operatorname{BAZ}(n=13)$ & 9 & 360 \\
\hline GOKI & Budapest (n=163) & Pest $(n=85)$ & 51 & 299 \\
\hline Pécs & Baranya $(n=205)$ & Tolna $(n=69)$ & 22 & 296 \\
\hline Kecskemét & Bács (n=215) & Pest $(n=29)$ & 3 & 247 \\
\hline Szolnok & Jász (n=192) & Pest ( $n=43)$ & 7 & 242 \\
\hline Bajcsy & Budapest $(n=130)$ & Pest (n=83) & 28 & 241 \\
\hline Debrecen & Hajdú (n=182) & Jász (n=29) & 25 & 236 \\
\hline Balatonfüred & Veszprém (n=195) & Somogy $(n=11)$ & 25 & 231 \\
\hline Győr & Győr (n=206) & Komárom (n=19) & 6 & 231 \\
\hline Zalaegerszeg & Zala $(n=189)$ & $\operatorname{Vas}(n=9)$ & 11 & 209 \\
\hline Szombathely & Vas $(n=123)$ & Győr (n=62) & 3 & 188 \\
\hline BIK & Budapest $(n=70)$ & Pest $(n=71)$ & 42 & 183 \\
\hline Kaposvár & Somogy (n=128) & Tolna $(n=24)$ & 14 & 166 \\
\hline
\end{tabular}

kunder transzport). Figyelemre méltó, hogy a panasz fellépésének idejétől számítva csak a betegek 6,2\%ánál sikerült az érmegnyitást 120 percen belül elvégezni, míg minden ötödik betegnél $(21,6 \%)$ a teljes iszkémiás idő meghaladta a 12 órát. $A z$ érmegnyitás alkalmával a betegek 94,9\%-a kapott stentet. A beültetett stentek 50,43\%-a DES volt. A vizsgáló által szövődménynek tartott esemény a beavatkozások 1,71\%-ánál fordult elő.

\section{A nem ST-elevációval járó szívinfarktusos} betegek ellátása

Az NSTEMI-diagnózissal kezelt betegek 75,9\%-a szívkatéteres centrumban kapott kezelést. A betegek $56,7 \%$-ánál történt $\mathrm{PCl}$. A szívkatéterezést a beavatkozások 92,3\%-ában radiális behatolásból végezték. Az érmegnyitás során a betegek 92,7\%-a kapott stentet, a DES-arány $62,1 \%$. Szövődményt a beavatkozások 2,5\%-ában rögzítettek.

\section{Az invazív centrumok által ellátott}

STEMI-betegek lakóhely szerinti megoszlása A STEMI-diagnózissal kezelt betegek lakóhely szerint megoszlását vizsgálva azt találtuk, hogy az ellátott betegek több megyéből érkeznek a centrumba. A 2. táblázatban feltüntettük a centrum által ellátott betegek számát, valamint azokat a megyéket ahonnan betegeket fogadtak.

\section{A STEMI, illetve NSTEMI-diagnózissal} kezelt betegek kórházï, 30 napos és 1 éves halálozása

A halálozással kapcsolatos részletes adatokat diagnózis és évek szerint a 3. táblázat tartalmazza. Kiemelen-

3. TÁBLÁZAT. Az NSZR-ben rögzített infarktusos betegek kórházi, 30 napos és 1 éves halálozása

\begin{tabular}{|c|c|c|c|c|c|c|}
\hline & \multicolumn{3}{|c|}{ STEMI } & \multicolumn{3}{|c|}{ NSTEMI } \\
\hline & 2014 & 2015 & 2016 & 2014 & 2015 & 2016 \\
\hline Kórházi halálozás (\%) & 8,3 & 8,4 & 9,6 & 6,6 & 7,4 & 7,8 \\
\hline 30 napos halálozás (\%) & 13,2 & 12,9 & 13,5 & 11,3 & 11,8 & 12,0 \\
\hline PCl történt & 8,8 & 9,1 & 9,8 & 5,1 & 5,8 & 6,5 \\
\hline 1 éves halálozás (\%) & 21,4 & 19,9 & - & 23,3 & 23 & - \\
\hline $\mathrm{PCl}$ történt & 15,0 & 15,1 & - & 12,9 & 14,2 & - \\
\hline
\end{tabular}




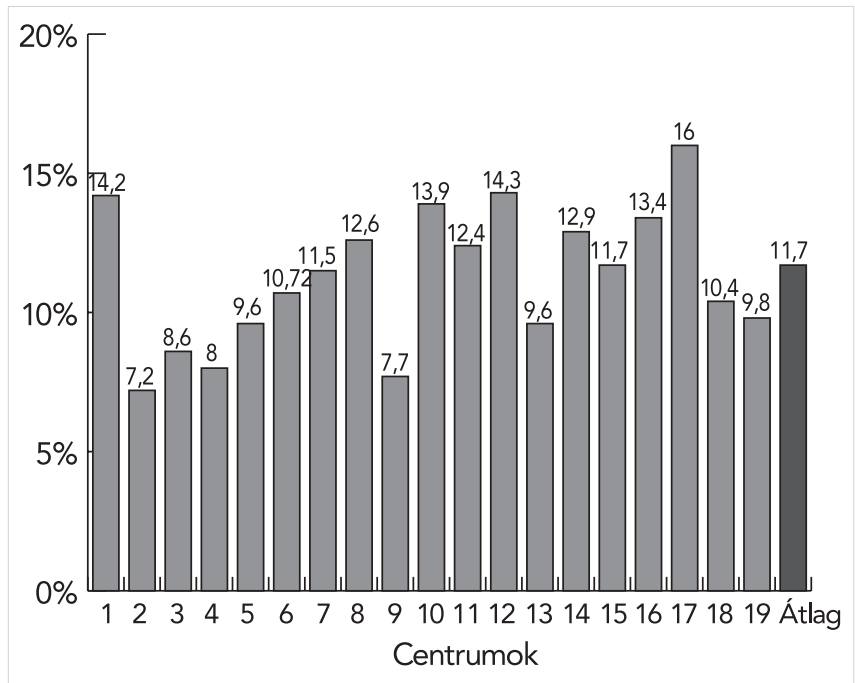

1. ÁBRA. A szívkatéteres centrumokban kezelt STEMI-betegek 30 napos halálozása (2016)

dő, hogy az évek között elhanyagolható a különbség. Az NSTEMI-betegcsoport prognózisa halálozása mind a kórházi, mind a 30 napos időperiódusban kedvezőbb, mint az ST-eleváció miatt kezelt betegeké. Az 1 éves időszakban a helyzet megváltozik az NSTEMI-betegeknél lényegesen magasabb a halálozás. A PCI-keze-

4. TÁBLÁZAT. A prehospitális időszakban újraélesztett, illetve a felvételkor kardiogén sokkban lévő betegek gyakorisága

\begin{tabular}{|l|c|c|}
\hline Centrum & $\begin{array}{c}\text { Prehospitalis } \\
\text { idöszakban } \\
\text { reszuszcitált } \\
\text { betegek aránya } \\
\text { (\%) }\end{array}$ & $\begin{array}{c}\text { A kórházi } \\
\text { felvételkor } \\
\text { kardiogén } \\
\text { sokkban lévö } \\
\text { betegek aránya }\end{array}$ \\
\hline Bajcsy & 3,7 & 3,3 \\
\hline Balatonfüred & 5,5 & 7,2 \\
\hline BIK & 4,8 & 5,9 \\
\hline Debrecen & 4,0 & 6,0 \\
\hline GOKI & 6,3 & 7,6 \\
\hline Györ & 3,0 & 3,9 \\
\hline Gyula & 1,0 & 5,8 \\
\hline Honvéd & 8,4 & 7,2 \\
\hline Kaposvár & 1,8 & 4,2 \\
\hline Kecskemét & 4,0 & 4,4 \\
\hline Miskolc & 3,2 & 3,4 \\
\hline Nyíregyháza & 4,1 & 7,7 \\
\hline Pécs & 6,7 & 3,0 \\
\hline SE VSZÉK & 7,6 & 4,9 \\
\hline Szeged & 3,4 & 2,6 \\
\hline Székesfehárvár & 4,8 & 4,3 \\
\hline Szolnok & 4,1 & 5,4 \\
\hline Szombathely & 8,3 & 8,3 \\
\hline Zalaegerszeg & 2,3 & 6,5 \\
\hline Átlag & 4,9 & \\
\hline & & 5,2 \\
\hline
\end{tabular}

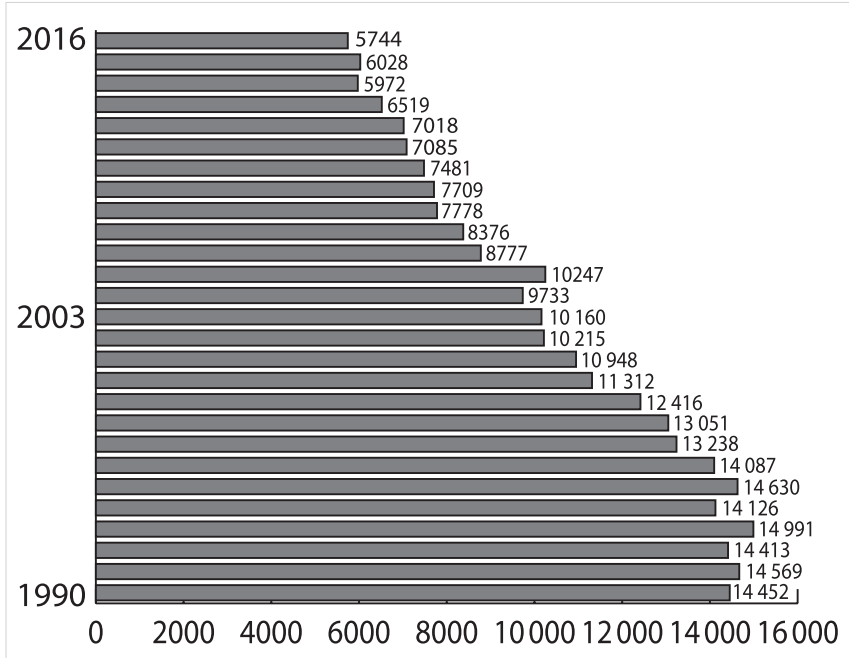

2. ÁBRA. Szívinfarktus következtében meghalt betegek száma 1990-2016 (KSH adatok)

lésben részesült betegeknek - mindkét típusú infarktus esetén -, mind a 30 napos, mind az 1 éves időpontban lényegesen jobb volt a prognózisuk.

\section{A különböző invazív centrumban kezelt STEMI-betegek 30 napos halálozása}

A különböző invazív centrumokban kezelt STEMI-betegek 30 napos halálozását az 1. ábra mutatja. Két centrumot az elemzésből kihagytunk, amelyek a finanszírozott események kevesebb, mint 70\%-át regisztrálták (1. táblázat). A 30 napos halálozás a centrumok között jelentősen különbözik. A 4. táblázatban feltüntettük a prehospitális időszakban újraélesztett, illetve a felvételkor kardiogén sokkban lévő betegek arányát, ami centrumonként ugyancsak eltérő gyakorisággal fordult elő. A centrumok nyilvánvalóan eltérő súlyosságú betegeket kezeltek, ebből következik, hogy az eltérő halálozási adatok önmagukban nem alkalmasak a kezelés eredményességének összehasonlítására.

\section{Szívinfarktus födiagnózissal meghalt betegek száma - KSH-adatok}

A Központi Statisztikai Hivatal évek óta közzéteszi a szívinfarktus fődiagnózissal meghalt betegek évenkénti számát. A 2. ábra mutatja a 1990-2016 közötti adatokat. Jól látható, hogy 1990 óta jelentősen - mintegy 60\%-kal - csökkent az infarktus következtében meghalt betegek száma és 2014-2016 években 6000 körül stabilizálódott.

\section{A hazai eredmények a nemzetközi közlések tükrében}

Az Európai Kardiológus Társaság 2017. évi kongreszszusán a svéd infarktus regiszter 20 éves adatait is- 
mertették (2). 2013-2014-ben a SWEDEHEART adatai szerint az ST-eleváció miatt kezelt betegek 82\%-ánál történt reperfúziós kezelés 78\%-nál primer $\mathrm{PCI}, 3,7 \%$ ban trombolízis. Saját anyagunkban a STEMI-betegek $83,2 \%$-ánál történt primer $\mathrm{PCl}$, a trombolízisben részesült betegek aránya nem érte el a 0,5\%-ot. A trombolízis elhanyagolható gyakorisága miatt az alkalmazásának, körülményeinek vizsgálata jelenleg nem jön szóba. A SWEDEHEART-betegek esetén panasz kezdet és a trombolízis megkezdése közötti medián idő $160, \mathrm{PCl}$ esetén 190 perc volt. Saját anyagunkban ez az idő lényegesen hosszabb volt: a panasz kezdet és az ér megnyitása között idő mediánja 2014-ben 285, 2015-ben 271, 2016-ban 283 perc volt. Az NSZR rendelkezésére álló adatok nem teszik lehetővé a prehospitalis késés okainak elemzését, ezért jelenleg folyamatban van az Országos Mentőszolgálattal történő együttmúködés kialakítása. A 30 napos és az 1 éves halálozás 2013/2014. években, Svédországban 9,2\%, illetve $14,1 \%$ volt. Saját betegeinknél a 30 napos halálozás a 2014-2016. években 13\%, az 1 éves érték $20 \%$ körül volt. A lényeges különbség több tényezővel magyarázható. Egy korábbi közleményünkben rámutattunk arra, a magyar populációnál lényegesen magasabb a társbetegségek aránya, és ez a halálozásban meglévő különbségeket részben magyarázza (3). A hazai kedvezőtlen adatok további magyarázata, hogy elfogadhatatlanul hosszú a panasz kezdetétől az ér megnyitásáig eltelt idő és indokolatlanul alacsony a katéteres intervenciót megelőző trombolízis aránya, azon betegeknél, akiknél 120 percen belül nem kerül sor in- tervencióra. Hazánkban a 120 percen belül revaszkularizációban részesült betegek aránya 2016-ban mindössze $6,2 \%$. További vizsgálatok indokoltak a magas, 1 éves halálozás okainak megismerése érdekében. A kedvezőtlen késői prognózis egyik oka a nem megfelelő adherencia a szekunder prevenció szempontjából fontos gyógyszeres kezeléshez (4). Az infarktust követő intézeti és ambuláns rehabilitációra, illetve a túlélt betegek életmódváltozására vonatkozó reprezentatív adatok jelenleg nem állnak rendelkezésre.

\section{Köszönetnyilvánítás}

A szerző köszöni és nagyra értékeli az együttmüködő centrumok, valamit az NSZR munkatársainak tevékenységét.

\section{Irodalom}

1. Jánosi A. A szívinfarktus miatt kezelt betegek ellátásának és prognózisának fontosabb adatai - Nemzeti Szívinfarktus Regiszter 2015. Cardiologia Hungarica 2016; 46: 70-75.

2. Szummer K, Wallentin L. Lindhagen, et al. Improved outcomes in patients with ST-elevation myocardial infarction during the last 20 years are related to implementation of evidence based treatments: expreineces from the SWEDEHEART registry 1995-2014. Eur Heart J 2017; 0: 1-10.

3. Szummer K, Jánosi A, Breuer T, et al. Comparable 30-day outcome in ST elevation myocardial infarction patients treated in Sweden or Hungary-results from SWEDEHEART and the Hungarian Infarction Registry. European Heart Journal 2013; 34(Suppl 1): 457.

4. Jánosi $A$, Ofner P, Kiss Z, Kiss L, et al. Szívinfarktust túlélt betegek terápiahűsége a másodlagos megelőzés szempontjából fontos gyógyszeres kezeléshez. Orv Hetil 2017; 158: 1051-1057.

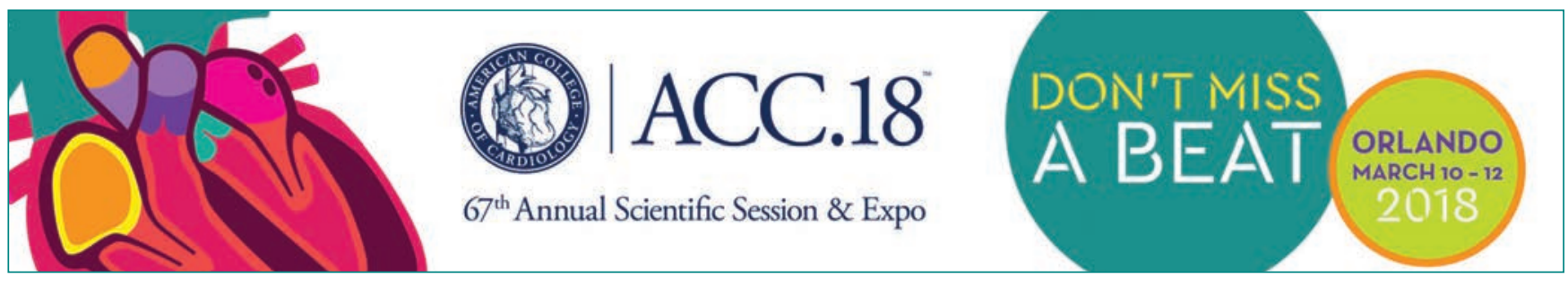

